\title{
New provincial records of the cave cricket Dolichopoda euxina Semenov, 1901 (Orthoptera) from Republic of Adygea (Russia) with notes on its conservation status
}

\author{
Новые региональные находки пещерника кавказского \\ Dolichopoda euxina Semenov, 1901 (Orthoptera) \\ из Республики ААыгея (Россия) с замечаниями \\ о его природоохранном статусе
}

\author{
M.I. Shapovalov ${ }^{1}$, A.S. Zamotajlovi, 2 , A.S. Bondarenko ${ }^{3}$ \\ М.И. Шаповахов ${ }^{1}$, А.С. Замотаймов ${ }^{1,2}$, А.С. Бондаренко ${ }^{3}$
}

\begin{abstract}
${ }^{1}$ Laboratory of Bioecological Monitoring of Invertebrate Animals of Adygea, Complex Problems Research Institute, Adygei State University, Gagarin str., 13, Maykop, Republic of Adygea 385000 Russia. E-mail: maksimshapovalov1@rambler.ru

${ }^{2}$ Kuban State Agrarian University, Kalinin str., 13, Krasnodar 350044 Russia. E-mail: a_zamotajlov@mail.ru

${ }^{3}$ Russian Centre of Forest Health, Branch Centre of Forest Health of Krasnodar Region, Odesskiy passage, 4, Krasnodar 350020 Russia.

E-mail: bondt@yandex.ru

${ }^{1} \Lambda$ аборатория биоэкологического мониторинга беспозвоночных животных ААыгеи НИИ комплексных проблем ААыгейского государственного университета, ул. Гагарина, 13, Майкоп, Республика Адыгея 385000 Россия

${ }^{2}$ Кубанский государственный аграрный университет, ул. Кахинина, 13, Краснодар 350044 Россия

${ }^{3}$ Российский центр защиты кеса, фикиал Центр защиты меса Краснодарского края, ОАесский проезА, 4, Краснодар 350020 Россия
\end{abstract}

Key words: Orthoptera, cave cricket Dolichopoda euxina, new records, conservation status, Caucasus, Republic of Adygea. Ключевые слова: Orthoptera, пещерный кузнечик Dolichopoda euxina, новые находки, природоохранный статус, Кавказ, Республика Адыгея.

Abstract. New Caucasian records of the cave cricket Dolichopoda euxina Semenov, 1901 from the territory of Republic of Adygea are given, it is recorded for Adygea for the first time. Sozological status of the cricket is discussed.

Резюме. Приводятся новые на Кавказе находки пещерника кавказского Dolichopoda euxina Semenov, 1901 с территории Республики ААыгея; этот виА впервые отмечается Аля ААыгеи. Обсуждается созологический статус пещерника.

The Caucasian cave cricket Dolichopoda euxina Semenov, 1901 has been hitherto recorded from the Caucasus and the North-East Turkey only, all known Caucasian populations being located at the Black Sea Coast and adjacent territories within the limits of Georgia (including Abkhazia and South Ossetia) and Krasnodar Region of Russia [Stolyarov, 1994, 2005]. Still no definite records of the cricket have been given for the territory of Adygea [Shchurov, 2012], even numerous finds already listed for the neighboring regions in Apsheronsk, Goryachiy Klyuch, Mostovskoy, Severskaya districts, Sochi Municipality and Arkhipo-Osipovka settlement of Krasnodar Region [Stolyarov, 2007].

The Caucasian cave cricket is interpreted by Stolyarov [1960] and some other authors as a relic species, deserving special conservation measures. Noteworthy, this point of view is supported by the recent federal experts, who offered for it a particular sozological status [The list..., 2014]. According to the IUCN Red List Categories and Criteria [2012], the Caucasian cave cricket is listed (evaluated) as critically endangered taxon. It is included in the regional red data books of both Krasnodar Region [Stolyarov, 2007] and Republic of Adygea [Shchurov, 2012] with the similar category "Facing the risk of extinction". The cricket seems to be the most easily distinguishable and perspective cave "umbrella" species in the Caucasus, with the quite narrow ecological specialization, inhabiting caves, grottoes, artificial galleries, usually deposited mainly within the forest belt.

Below some new Caucasian records of this species from the territory of Republic of Adygea are given, followed by the observation year and month:

1. Dakhovskaya Cave. Situated at rocky cuesta of Unakoz Mt. Range near Dakhovskaya village. May 1985.

2. Priamaya Cave. Situated at cuesta of Azishtau Mt. Range at the bottom of its East rocky wall. May 1995.

3. Budkova Cave (Fig. 1). Situated SE of Novosvobodnaya village at the left bank of Lakrush River in the basis of the rocky exposure almost at the ridge crest. Being the largest karst cavity of all studied, it represents a multilevel labyrinth with numerous halls chambers. May 2013.

4. Ovechya Cave. Situated in Alpine zone near mouth of Molochka River (left tributary of Kurdzhips River). June 2013.

5. $100 \mathrm{~m}$ artificial gangway in the vicinities of Dakhovskaya village, valley of Sibir' River (right tributary of Belaya River), entrance situated at $650 \mathrm{~m}$ in the beechhornbeam forest. May 2014.

6. Right bank of Belaya River near Dakhovskaya village, 


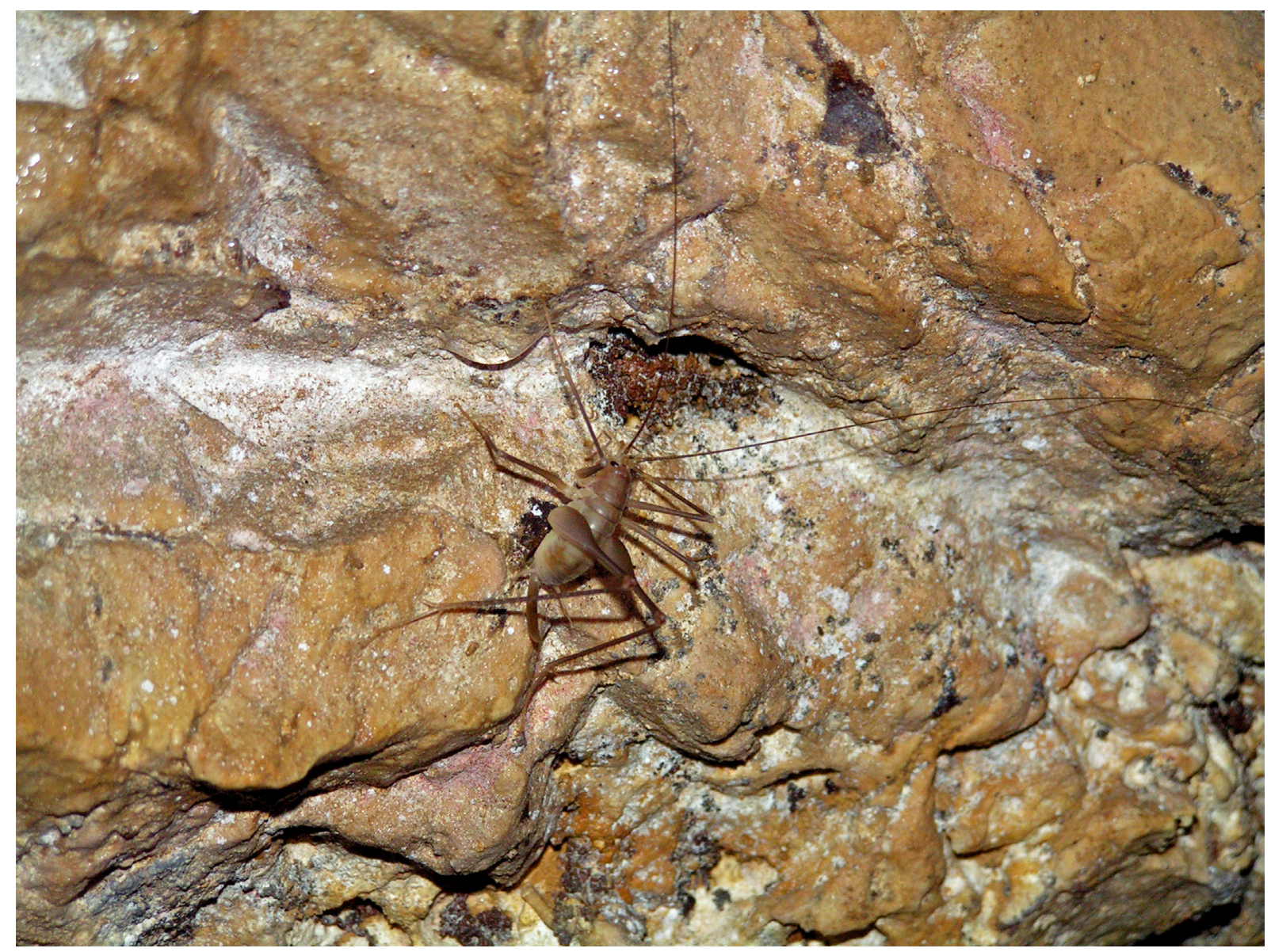

Fig. 1. Caucasian cave cricket Dolichopoda euxina Semenov, 1901 at ceiling of the chamber of Budkova Cave, Republic of Adygea, May 2013. Рис. 1. Пещерник кавказский Dolichopoda euxina Semenov, 1901 на своде камеры пещеры Будкова, Республика ААыгея, май 2013 года.

SW exposition of Skalistyi Mt. Range, rocky taluses in the beech- hornbeam forest, $530 \mathrm{~m}$. May 2014.

7. Left bank of Belaya River near Skala site, rocky taluses in the oak-hornbeam forest, $850 \mathrm{~m}$. May 2014.

One further population has been also found in 2014 in the karst cavity at Azishtau Mt. Range (nameless glade near Ardova Polyana site), fir-mixed forest, 1450 m. Even it is deposited in Krasnodar Region, this locality is spatially quite close to Adygea, this fact allows to assume existence of species' populations in the nearby natural boundary Tserbelevy Polyany.

Obviously, the main threat to the known local populations is now caused by possible degradation of the cave ecosystems as a result of the increasing uncontrollable recreational impact. However, all studied natural objects from Adygea, populated by D. euxina, do not represent the large karstic cavities usually visited by cave explorers and tourists, therefore this factor seems to be not limiting there. On the contrary, intensive forest exploitation may essentially affect change of the subterranean microclimatic conditions and lead to extinction of the species in question.

Due to sharply expressed specifics of the habitats within its whole distribution area, this species is represented in nature by the separate isolated populations. Geographical isolation and ecological insularization of such populations make impossible their effective natural restoration. System development of tourist and recreational resources of
Krasnodar Region and the Republic of Adygea, observed in the recent years, has led to considerable degradation of the subterranean ecosystems of the region. Species' extinction could be expected in all open for visit and particularly equipped natural cavities. So allusion of the Caucasian cave cricket in the new edition of the Red Data Book of Russian Federation seems quite reasonable, even attributed data deficient survival threats status [The list..., 2014] seems to be not so suitable.

\section{Acknowledgements}

Authors wish to express their sincere thanks to all colleagues who contributed to the field studies and communicated useful information, particularly to our friend and colleague speleologist Dr. Andrey Ostapenko (Krasnodar, Russia).

\section{References}

IUCN Red List Categories and Criteria. Version 3.1. Second edition. 2012. Gland: IUCN. iv + 32 p.

Shchurov V.I. 2012. Caucasian cave cricket - Dolichopoda euxina Semenov, 1901. In: Krasnaya kniga Respubliki Adygeya. Redkie i nakhodyashchiesya pod ugrozoy ischeznoveniya ob"ekty zhivotnogo i rastitel'nogo mira. Chast' 2. Zhivotnye [Red Data Book of Republic of Adygheya. Rare and threatened representatives of the regional fauna and flora. Part 2. Animals]. Maykop: Kachestvo: 55 (in Russian). 
Stolyarov M.V. 1960. Peculiarities of the geographic distribution, ecology and biology of grasshoppers of Abkhazia. Entomologicheskoe obozrenie. 39(4): 761-774 (in Russian).

Stolyarov M.V. 1994. Regularities of genesis of the orthopterous insects fauna (Orthoptera) of Transcaucasia. 4. Species of genera possessing Ancient Mediterranean and Turan origin. Entomologicheskoe obozrenie. 73(1): 66-79 (in Russian).

Stolyarov M.V. 2005. New data on distribution and taxonomy of the orthopterous insects (Orthoptera) of the Caucasus. 1. Gryllacridoids (Stenopalmatoidea) and tettigonoid grasshoppers (Tettigonidae). Trudy Russkogo entomologicheskogo obshchestva. 76: 62-171 (in Russian).

Stolyarov M.V. 2007. Caucasian cave cricket - Dolichopoda euxina Semenov, 1901. In: Krasnaya kniga Krasnodarskogo kraya (zhivotnye)
[Red Data Book of Krasnodar Territory (Animals)]. Krasnodar: Center for Information and Economic Development of the Press, Television and Radio of Krasnodar Region: 96-97 (in Russian).

Perechen' taksonov i populyatsiy nazemnykh bespozvonochnykh zhivotnykh, rekomendovannykh sektsiey ekspertov po nazemnym bespozvonochnym dlya zaneseniya $\mathrm{v}$ Perechen' taksonov i populyatsiy zhivotnykh, nuzhdayushchikhsya $\mathrm{v}$ osobom vnimanii $\mathrm{k}$ ikh sostoyaniyu v prirodnoy srede (Prilozhenie $3 \mathrm{k}$ Krasnoy knige Rossiyskoy Federatsii). Proekt [The list of taxa and populations of the land invertebrate animals recommended by the section of experts on land invertebrates for entering in the List of taxa and populations of animals, requiring special attention to their condition in the natural environment (The annex 3 to the Red Data Book of the Russian Federation). Project]. 2014. Moscow. 75 p. (in Russian). 